\title{
In vitro Antiproliferative activity of Melissa officinalis L. (Lamiaceae) leaves essential oil
}

\author{
[Actividad antiproliferativa in vitro de aceite esencial de hojas de Melissa officinalis L (Lamiaceae)] \\ Haris Nikšić ${ }^{1}$, Kemal Durić1, Irma Sijamić ${ }^{1}$, Emina Korić ${ }^{1}$, Jasna Kusturica ${ }^{2}$, \\ Elma Omeragić ${ }^{1} \&$ Samija Muratovic ${ }^{1}$ \\ ${ }^{1}$ Faculty of Pharmacy University of Sarajevo, Zmaja od Bosne 8, 71000 Sarajevo, Bosnia and Herzegovina \\ ${ }^{2}$ Faculty of Medicine University of Sarajevo, Čekaluša 90, 71000 Sarajevo, Bosnia and Herzegovina \\ Contactos | Contacts: Haris NIKŠIĆ - E-mail address: haris.niksic@ffsa.unsa.ba
}

\begin{abstract}
In the present study, we investigated the antiproliferative activity of essential oil from leaves of Melissa officinalis L. grown in Southern Bosnia and Herzegovina. In vitro evaluation of antiproliferative activity of the M. officinalis essential oil was carried out on three human tumor cell lines: MCF-7, NCI-H460 and MOLT-4 by MTT assay. M. officinalis essential oil was characterized by high percentage of monoterpenes $(77,5 \%)$, followed by the sesquiterpene fraction $(14,5 \%)$ and aliphatic compounds $(2,2 \%)$. The main constituents of the essential oil of M. officinalis are citral (47,2\%), caryophyllene oxide (10,2\%), citronellal $(5,4 \%)$, geraniol $(6,6 \%)$, geranyl acetate $(4,1 \%)$ and $\beta$ - caryophyllene $(3,8 \%)$. The essential oil showed significant antiproliferative activity against three cancer cell lines, MOLT-4, MCF-7, and NCI-H460 cells, with GI50 values of $<5,6 \pm 2$ and $31 \pm 17 \mu \mathrm{g} / \mathrm{mL}$, respectively. The results revealed that M. officinalis L. essential oil has a potential as anticancer therapeutic agent.
\end{abstract}

Keywords: Melissa officinalis L.; essential oil; antiproliferative agents; MOLT-4; MCF-7; NCI-H460

Resumen: En el presente estudio, investigamos la actividad antiproliferativa del aceite esencial de las hojas de Melissa officinalis L. cultivadas en el sur de Bosnia y Herzegovina. La evaluación in vitro de la actividad antiproliferativa del aceite esencial de $M$. officinalis se llevó a cabo en tres líneas celulares de tumores humanos: MCF-7, NCI-H460 y MOLT-4 utilizando el ensayo de MTT. El aceite esencial de M. officinalis se caracterizó por un alto porcentaje de monoterpenos $(77,5 \%)$, seguido de la fracción sesquiterpénica (14,5\%) y compuestos alifáticos (2,2\%). Los principales constituyentes del aceite esencial de M. officinalis fueron citral (47,2\%), óxido de cariofileno (10,2\%), citronelal (5,4\%), geraniol (6,6\%), acetato de geranilo (4, 1\%), y $\beta$-cariofileno $(3,8 \%)$. El aceite esencial mostró una actividad antiproliferativa significativa contra las líneas celulares de cáncer MOLT-4, MCF-7 y NCI-H460, con valores GI50 de <5, $6 \pm 2$ y $31 \pm 17$ $\mu \mathrm{g} / \mathrm{mL}$, respectivamente. Los resultados revelaron que el aceite esencial de $M$. officinalis $\mathrm{L}$. tiene potencial como agente terapéutico contra el cáncer.

Palabras clave: Melissa officinalis L.; Aceite esencial; Agentes antiproliferativos; MOLT-4; MCF-7; NCI-H460

Recibido | Received: March 22, 2019

Aceptado | Accepted: May 30, 2019

Aceptado en versión corregida | Accepted in revised form: June 12, 2019

Publicado en línea | Published online: September 30, 2019

Este artículo puede ser citado como / This article must be cited as: H Nikšić, K Durić, I Sijamić, E Korić, J Kusturica, E Omeragić, S Muratovic. 2019 In vitro Antiproliferative activity of Melissa officinalis L. (Lamiaceae) leaves essential oil. Bol Latinoam Caribe Plant Med Aromat 18 (5): 480 - 491.

Https://doi.org/10.35588/blacpma.19.18.5.31 


\section{INTRODUCTION}

Cancer is a complex disease that can affect any part of the body and is the second leading cause of morbidity and mortality worldwide (WHO, 2018). The global cancer burden is estimated to have risen to 18.1 million new cases and 9.6 million deaths in 2018. Worldwide, the total number of people who are alive within 5 years of a cancer diagnosis, celled the 5 -year prevalence, is estimated to be 43.8 million. Cancer of the lung and female breast are the leading types worldwide in terms of the new cases; for each of these types, approximately 2.1 million diagnoses are estimated in 2018, contributing about $11.6 \%$ of the total cancer burden (WHO, 2018). Acute lymphoblastic leukemia is the most common hematological cancer in children and adolescents, representing $20 \%$ of all cancers diagnosed in persons aged $<20$ years in the United States (Ward et al., 2014).

The study of natural products has been the single most successful strategy for the discovery of new medicines used in anticancer therapy and more than two thirds of drugs currently used for cancer treatment have plant origin. Key hallmarks of cancer include resisting cell death, sustained proliferative signaling, and evading growth suppressors (Amin et al., 2009). Therefore, chemotherapy often relies on the characteristics of drugs to reduce the ability of cancer cells to grow and divide and to induce cell damage and death. With the aim of testing possible use as alternative or complementary cancer treatments, several essential oils (EOs) are under investigation for their cytotoxic and antiproliferative actions in cancer cell lines or tumor bearing animals (Edris, 2007; Lesgards et al., 2014). Different mechanisms may account for the reported cytotoxic effects of EOs or their constituents. These include induction of cell death by apoptosis and/or necrosis, cell cycle arrest, and loss of key organelles function.

EOs, secondary metabolites of plants are mixtures of small molecular chemical compounds, mainly terpenes and phenols, with biological action. Essential oils are proved to have various pharmacological effects, such as spasmolytic, carminative, hepatoprotective, antioxidative, antimicrobial, and anticarcinogenic effects (Blowman et al., 2018). EOs have been shown to possess anticancer properties through various mechanisms, including antimutagenic, antiproliferative, antioxidant, and detoxifying capabilities acting on various pathways in the cancer cell as well as cancer preventative capabilities (Edris, 2007). Specific EO constituents have been shown to enhance the cytotoxic activity of chemotherapy drugs (Docetaxel, Paclitaxel, 5-fluorouracil) in various cell lines, thus increasing the therapeutic window, that is, lowering the required drug concentrations while providing the same effect (Carnesecchi et al., 2004; Legault \& Pichette, 2007; Raby \& Bishayee, 2009).

Lemon balm, Melissa officinalis L. (Lamiaceae) is a well-known used medical plant in Europe. M. officinalis L. is a perennial herb and it is indigenous of Southern Europe, Mediterranean region, Western Asia, and North Africa. $M$. officinalis L. is now cultivated worldwide. $M$. officinalis L. occurs naturally in sandy and scrubby areas but has also been reported to grow on damb wasteland, at elevations ranging from sea level to the mountains (Miraj et al., 2017). The leaf of $M$. officinalis L. contains flavonoids (quercitrin, rhamnocitrin, luteolin), polyphenolic compounds (rosmarinic acid, caffeic acid and protocatechuic acid), monoterpenoid aldehyde, monoterpene glycosides, triterpenes (ursolic and oleanolic acids), sesquiterpenes, tannins and essential oil. Thirty-three components were identified representing $89.30 \%$ of the total oil in the composition of the leaf. Predominant components in M. officinalis L. leaves essential oil are: citronellal, isogeraniol, geraniol acetate, nerol acetate, caryophyllene and caryophyllene oxide (Miraj et al., 2017). Some pharmacological properties have been attributed to M. officinalis L. including antimicrobial, antidepressant, hypnotic, hypoglycemic, hepatoprotective and sedative (Miraj et al., 2016). M. officinalis L. essential oil has been shown to possess antibacterial, antifungal and spasmolytic activities (Sadraei et al., 2003; Mimica-Dukic et al., 2004), while antitumoral effect has only recently been reported. There has been accumulating evidence supporting the use of $M$. officinalis L. as an anticancer agent (de Sousa et al., 2004; Encalada et al., 2011; Saraydin et al., 2012; Unver et al., 2012; Jahanban-Esfahlan et al., 2015; Moaca et al., 2018).

With respect to this topic, this paper focuses on the analysis of the antiproliferative activity of the chemically characterized $M$. officinalis L. essential oil against breast adenocarcinoma (MCF-7) cell line, lung carcinoma (NCI-H 460) cell line and acute lymphoblastic leukemia (MOLT-4) cell line. 


\section{MATERIALS AND METHODS}

\section{Plant material}

The aerial parts of flowering, wild growing, in the first year of growth, plant Melissa officinalis L. were collected in June 2015. in the south region of Bosnia and Herzegovina (location: nearby the Jablanicko

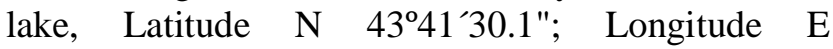
$\left.17^{\circ} 50^{\prime} 12.3^{\prime \prime}\right)$. The taxonomic identification of plant materials, Voucher specimen No.115/15, was confirmed by a senior plant taxonomist, Prof. Samir Đug, and deposited at the Herbarium of the Department of Biology, Faculty of Sciences, University of Sarajevo.

After plant material (3 $\mathrm{kg})$ have been collected, the samples were dried at room temperature and the leaves were manually separated from steams. Leaves were manually crushed and stored under nitrogen atmosphere.

\section{Isolation of the essential oil}

A total of $20 \mathrm{~g}$ air-dried leaves of $M$. officinalis L. was subjected to hydrodistillation for $2,5 \mathrm{~h}$ with 400 $\mathrm{mL}$ distilled water using a Clevenger-type apparatus (Klaus Hofmann GmbH, Germany) according to the European Pharmacopoeia (2010). The obtained oil was collected and dried over anhydrous sodium sulphate and stored in a refrigerator at $4-5^{\circ} \mathrm{C}$ in a dark glass vial prior to analysis. The quantity of the predestilated essential oils was determined volumetrically.

Identification of essential oil components by gas chromatography/mass spectroscopy (GC/MS)

The chemical composition of the essential oils was analyzed using GC/MS system (DSQ II GC/MS with Trace GC Ultra, Thermo Scientific, Palo Alto, USA). Capillary column ZB-5 MS $30 \mathrm{~m}$ x $0.25 \mathrm{~mm}$, film thickness $0.2 \mu \mathrm{m}$, was used (Phenomenex, Torrance, USA) with temperature program $60^{\circ} \mathrm{C}(1 \mathrm{~min})$ rising to $250^{\circ} \mathrm{C}$ at rate of $4^{\circ} \mathrm{C} / \mathrm{min}$. Helium was used as carrier gas at a flow rate of $1 \mathrm{~mL} / \mathrm{min}$. The temperature of split/splitless injector was $260^{\circ} \mathrm{C}$, split ratio was 1:50 and transfer line temperature was set to $270^{\circ} \mathrm{C}$ for $\mathrm{GC} / \mathrm{MS}$ analyses. Samples were injected manually $(0.1 \mu \mathrm{L})$. Mass spectra were recorded at 70 $\mathrm{eV}$ (EI), the mass range was $45-350 \mathrm{~m} / \mathrm{z}$ and Xcalibur version 2.0.7. was used for results processing and quantification. The identity of the components was assigned by obtained GC/MS spectra and retention indices (RI) relative to $\mathrm{C}_{8}-\mathrm{C}_{20}$ n- alkanes. AMDIS program version 2.62 was used for GC/MS data processing using NIST library version 2.0. Spectra and obtained retention indices were compared with literature (Adams, 2007).

\section{Antiproliferative Activity}

The antiproliferative activity of the M. officinalis L. essential oil was determined using MTT assay (Sylvester, 2011). In vitro evaluation of antiproliferative activity of the $M$. officinalis $\mathrm{L}$. essential oil was conducted in Laboratory for systemic biomedicine, Division of molecular medicine, "Ruđer Bosković" Institute in Zagreb. The purpose of this study was to obtain the specific activity profile of lemon balm essential oil by the determination of the activity at different concentrations in an appropriately selected cell panel.

For this purpose, well-characterized cell lines with regard to tumor type, genotype, proliferation rates, growth characteristics (solid and hematological) and general drug sensitivity and resistance were used (three cell lines found in the National Cancer Institute cell line screen). A known antitumor compound doxorubicin was tested as a control (referent compound according to NCI protocol), in parallel with the tested compounds (Sylvester, 2011).

\section{Cell culturing}

The experiments were carried out on three human tumor cell lines: MCF7 (breast adenocarcinoma, ATCC $®$ HTB-22 ${ }^{\mathrm{TM}}$ ), NCI-H460 (lung carcinoma, large cell lung cancer (ATCC® ${ }^{\circledR}$ HTB-177 ${ }^{\mathrm{TM}}$ ) and MOLT-4 (acute lymphoblastic leukemia ATCC $®$ CRL-1582 ${ }^{\mathrm{TM}}$ ). Cell lines were obtained from American Type Culture Collection.

The cells were cultured as monolayers (MCF7 and NCI-H460) or suspension (MOLT-4) and maintained in RPMI 1640 medium, supplemented with $10 \%$ fetal bovine serum (FBS), $2 \mathrm{mM} \mathrm{L-}$ glutamine, $100 \mathrm{U} / \mathrm{ml}$ penicillin and $100 \mu \mathrm{g} / \mathrm{ml}$ streptomycin in a humidified atmosphere with $5 \%$ $\mathrm{CO}_{2}$ at $37^{\circ} \mathrm{C}$ (Sylvester, 2011).

\section{Proliferation assays}

Results were analyzed according to a slightly modified protocol used at the National Cancer Institute (DTP, 2016). The panel cell lines were inoculated in parallel onto a series of standard 96well micro titer plates on day 0 , at $1.2 \times 104$ cells $/ \mathrm{ml}$ (NCI-H460), $3 \times 104$ cells/ml (MCF7) or $1 \times 105$ 
cells/ml (MOLT-4), depending on the doubling times of specific cell line. Test substances were then added at $5 \mu \mathrm{g} / \mathrm{ml}, 10 \mu \mathrm{g} / \mathrm{ml}, 50 \mu \mathrm{g} / \mathrm{ml}, 100 \mu \mathrm{g} / \mathrm{ml}, 500 \mu \mathrm{g} / \mathrm{ml}$ or $1000 \mu \mathrm{g} / \mathrm{ml}$ concentrations and incubated for a further 72 hours. Doxorubicin was used in parallel as a control, reference compound and was added in five 10 -fold dilutions $\left(10^{-10}\right.$ to $\left.10^{-6} \mathrm{M}\right)$. Working dilutions were freshly prepared on the day of testing. The solvent dymethyl-sulphoxide (DMSO) was also tested for eventual inhibitory activity by adjusting its concentration to be the same as in working concentration (DMSO concentration never exceeded $0.1 \%$ ). After 72 hours of incubation, the cell growth rate was evaluated by performing the MTT assay, which detects dehydrogenase activity in viable cells. The MTT Cell Proliferation Assay is a colorimetric assay system, which measures the reduction of a tetrazolium component (MTT) into an insoluble formazan product by the mitochondria of viable cells. For this purpose, the substance treated medium was discarded and MTT was added to each well at a concentration of $20 \mu \mathrm{g} / 40 \mu \mathrm{l}$. After four hours of incubation, the precipitates were dissolved in $160 \mu \mathrm{l}$ of DMSO. The absorbance (A) was measured on a microplate reader at $570 \mathrm{~nm}$. The absorbance is directly proportional to the cell viability. The percentage of growth (PG) of the cell lines was calculated according to one or the other of the following two expressions:

$$
\begin{aligned}
& \text { If }\left(\mathbf{A}_{\text {test }}-\mathbf{A}_{\text {tzero }}\right) \geq 0 \text { then: } \\
& \mathbf{P G}=100 \times\left(\mathbf{A}_{\text {test }}-\mathbf{A}_{\text {tzero }}\right) /\left(\mathbf{A}_{\text {cont }}-\mathbf{A}_{\text {tzero }}\right) \\
& \text { If }\left(\mathbf{A}_{\text {test }}-\mathbf{A}_{\text {tzero }}\right)<0 \text { then: } \\
& \text { PG } \left.=100 \times\left(\mathbf{A}_{\text {test }}-\mathbf{A}_{\text {tzero }}\right) / \mathbf{A}_{\text {tzero }}\right)
\end{aligned}
$$

Where:

$\mathrm{A}_{\mathrm{tzero}}=$ the average absorbance before exposure of cells to the test compound

$\mathrm{A}_{\text {test }}=$ the average absorbance after the desired period of time $(72 \mathrm{~h})$

$\mathrm{A}_{\text {cont }}=$ the average absorbance after 72 hours with no exposure of cells to the test compound

Each test point was performed in quadruplicate in minimum three individual experiments. The results are expressed as concentration-response graph. The results are also expressed as $\mathrm{GI}_{50}$, a concentration necessary for inhibition of $50 \%$ of cell growth. Each result is a mean value from three separate experiments. The $\mathrm{GI}_{50}$ values for each compound are calculated from dose-response curves using linear regression analysis by fitting the test concentrations that give PG values above and below the respective reference value (e.g. 50 for $\mathrm{GI}_{50}$ ). Therefore, a "real" value for any of the response parameters was obtained only if at least one of the tested drug concentrations falls above, and likewise at least one falls below the respective reference value. If, however, for a given cell line all of the tested concentrations produce PG's exceeding the respective reference level of effect, then the lowest tested concentration is assigned as the default value. In screening data report, that default value is preceded by a "<" sign, signifying that the "real" value is something "less-than" the lowest tested concentration.

Likewise, if none of the tested concentrations produces the required PG reference level of effect or greater, then a ">" sign precedes the printed default value (which is the highest tested concentration), signifying that the "real" value is something "greaterthan" the highest tested concentration (Body \& Kenneth, 1995; Sylvester, 2011; DTP, 2016).

\section{RESULTS}

\section{Chemical composition analysis}

The oil of the leaves of M. officinalis L. isolated by hydrodistillation was of yellow-pale color with an agreeable perfumery odor, in total yield of $0.10 \%$ $(\mathrm{v} / \mathrm{w})$ on dry weight basis.

Qualitative and quantitative analytical results were obtained using GC-MS technique. Table No.1 shows the compounds identified in the oil of $M$. officinalis L. in order of elution on ZB-5 MS capillary column, the percentage content of the individual components, retention indices and chemical class distribution are summarized.

A total of 27 compounds were identified, representing $94.2 \%$ of the total content of the $M$. officinalis L. essential oil. This oil was characterized by high percentage of monoterpenes (77.5\%), especially oxygenated monoterpenes (57.1\%), followed by monoterpene alcohols (14.6\%), monoterpene esters (4.8\%) and monoterpene hydrocarbons $(1.0 \%)$. In contrast, the sesquiterpene fraction was lower (14.5\%); the oxygenated hydrocarbons $(10.2 \%)$ were detected in higher concentration than the hydrocarbons $(4.3 \%)$. Alipha- 
tic compounds represented $2.2 \%$ of the total oil.

Table No.1

Chemical Composition of M. officinalis L. essential oil

\begin{tabular}{|c|c|c|c|c|c|}
\hline $\begin{array}{l}\text { Pick } \\
\text { no. }\end{array}$ & Components $^{\mathrm{a}}$ & RT (minutes) & $\mathrm{RI}^{\mathrm{b}}$ & $\mathrm{RI}^{\mathrm{c}}$ & $\begin{array}{l}\text { percentage } \\
(\%)\end{array}$ \\
\hline 1 & 1-Octen-3-ol & 6.52 & 974 & 981 & 0.9 \\
\hline 2 & 6-Methyl-5-hepten-2-on & 6.65 & 988 & 986 & 1.3 \\
\hline 3 & Myrcene & 6.79 & 989 & 990 & 0.2 \\
\hline 4 & p-Cymene & 7.82 & 1020 & 1028 & 0.5 \\
\hline 5 & 1,8-Cineole & 8.06 & 1026 & 1036 & 0.4 \\
\hline 6 & trans- $\beta$-Ocimene & 8.43 & 1044 & 1049 & 0.3 \\
\hline 7 & Linalool & 10.12 & 1095 & 1100 & 2.1 \\
\hline 8 & $\alpha$-Thujone & 10.38 & 1101 & 1109 & 1.0 \\
\hline 9 & $\beta$-Thujone & 10.74 & 1112 & 1121 & 0.3 \\
\hline 10 & Camphor & 11.74 & 1141 & 1152 & 1.7 \\
\hline 11 & Citronellal & 11.84 & 1148 & 1155 & 5.4 \\
\hline 12 & Isomenthone & 12.13 & 1159 & 1163 & 0.9 \\
\hline 13 & trans-Verbanol & 12.76 & 1178 & 1181 & 1.2 \\
\hline 14 & Terpinen-4-ol & 12.83 & 1180 & 1183 & 0.4 \\
\hline 15 & $\alpha$-Terpineol & 13.31 & 1186 & 1196 & 0.3 \\
\hline 16 & Nerol & 14.26 & 1222 & 1226 & 1.5 \\
\hline 17 & Citronellol & 14.33 & 1223 & 1228 & 1.5 \\
\hline 18 & Citral & 14.76 & 1235 & 1241 & 47.2 \\
\hline 19 & Carvone & 14.95 & 1239 & 1247 & 0.2 \\
\hline 20 & Geraniol & 15.13 & 1249 & 1252 & 6.6 \\
\hline 21 & Methyl citronellate & 15.36 & 1255 & 1259 & 0.7 \\
\hline 22 & Thymol & 16.49 & 1289 & 1291 & 0.9 \\
\hline 23 & Carvacrol & 16.77 & 1298 & 1298 & 0.1 \\
\hline 24 & Geranyl acetate & 19.34 & 1379 & 1378 & 4.1 \\
\hline 25 & $\beta$-Caryophyllene & 20.71 & 1417 & 1420 & 3.8 \\
\hline 26 & Caryophyllene oxide & 25.69 & 1582 & 1582 & 10.2 \\
\hline 27 & $\alpha$-cadinol & 27.8 & 1650 & 1656 & 0.5 \\
\hline & total identified & 94.2 & & & \\
\hline & \multicolumn{3}{|c|}{ monoterpene hydrocarbons } & & 1.0 \\
\hline & \multicolumn{3}{|c|}{ monoterpene alcohols } & & 14.6 \\
\hline & \multicolumn{3}{|c|}{ oxygenated monoterpenes } & & 57.1 \\
\hline & \multicolumn{3}{|c|}{ monoterpene esters } & & 4.8 \\
\hline & \multicolumn{3}{|c|}{ sesquiterpene hydrocarbons } & & 4.3 \\
\hline & \multicolumn{3}{|c|}{ oxygenated sesquiterpenes } & & 10.2 \\
\hline & \multicolumn{3}{|c|}{ aliphatic compounds } & & 2.2 \\
\hline
\end{tabular}

a Compounds listed in order of elution from a ZB-5 MS column. b Literature retention indices.

${ }^{\mathrm{C}}$ indices relative to $\mathrm{C} 8-\mathrm{C} 20 \mathrm{n}$-alkanes on the ZB-5 MS column 
As shown in Table No. 1, oxygenated monoterpens such as citral $(47.2 \%)$ and citronellal (5.4\%), alcohol geraniol (6.6\%) and ester geranyl acetat $(4.1 \%)$ were the major components within the monoterpene fractions. Caryophyllene oxide (10.2\%) and $\beta$-caryophyllene $(3.8 \%)$ were dominated by the sesquiterpene fractions.

\section{Antiproliferative evaluation}

Results of the antiproliferative evaluation of tested essential oil are presented by Figure No. 1. Essential oil of the M. officinalis at 72 hours after treatment had inhibitory potential on proliferation of tested cancer cells. The results of the antiproliferative activity suggested that $M$. officinalis $\mathrm{L}$. essential oil induced a dose-dependent inhibition of cell viability in all tested tumor cell lines, although each culture showed different sensitivity. This oil demonstrated also a strong cytotoxic effect. A negative percentage indicates cytotoxicity following drug treatment where $-100 \%$ shows no cells survived the treatment at the specific drug concentration. Results of the antiproliferative evaluation of the doxorubicin, as referent drug, are presented by Figure No. 2 .

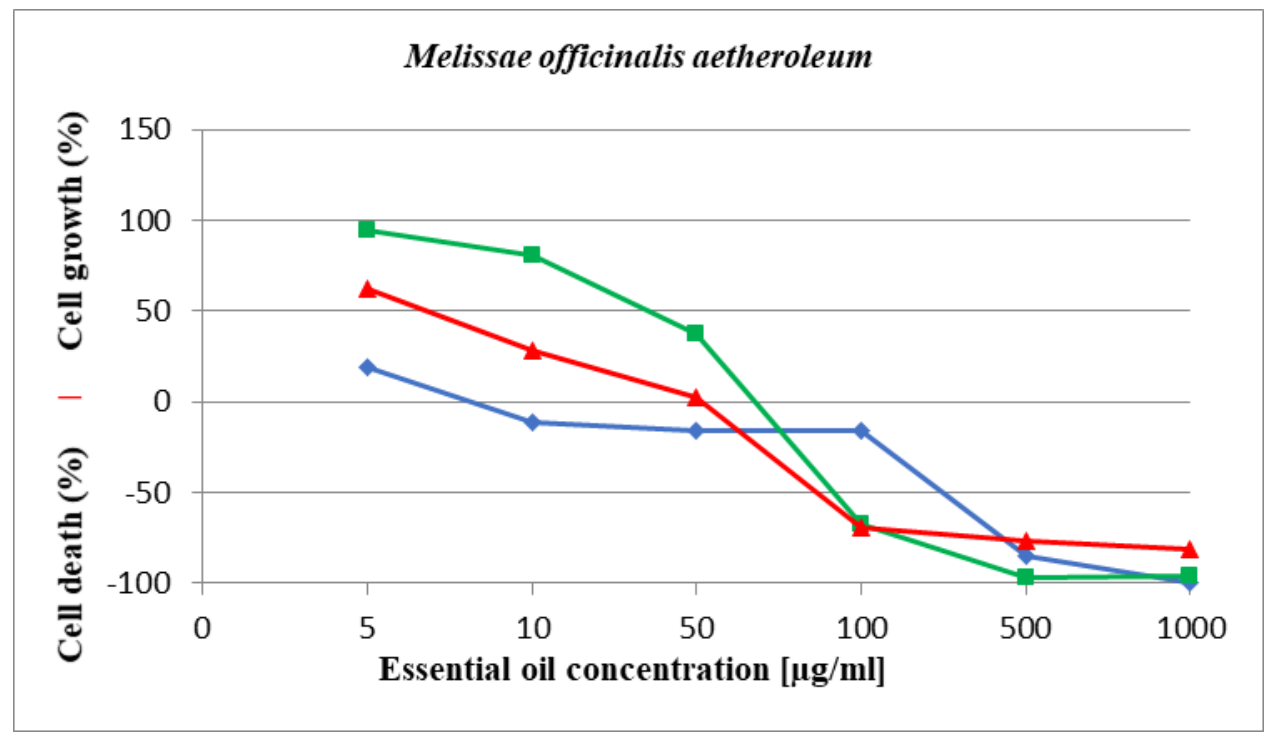

Figure No. 1

Growth inhibition of MOLT-4", NCI-H460-and MCF7 ${ }^{\star}$ cells in vitro, assessed by MTT assay 72 hours after the addition of $M$. officinalis $L$. essential oil

Table No. 2 presents the $\mathrm{GI}_{50}$ values which were determined from the dose-response curves of the oil and the used anticancer drug on MOLT-4, MCF-7 and NCI- H460 cells lines. The strongest antiproliferative activity of $M$. officinalis L. essential oil was observed against MOLT-4 cell line $\left(\mathrm{GI}_{50}<5\right.$ $\mu \mathrm{g} / \mathrm{ml})$ followed by MCF-7 cell line $\left(\mathrm{GI}_{50} 6 \mu \mathrm{g} / \mathrm{ml}\right)$ and NCI-H460 cells $\left(\mathrm{GI}_{50} 31 \mu \mathrm{g} / \mathrm{ml}\right)$. The strongest cytotoxic activity of $M$. officinalis L. essential oil was observed against solid tumor cell lines (MCF-7 and NCI-H460). At the applied dose of $100 \mu \mathrm{g} / \mathrm{ml}$ of $M$. officinalis L. essential oil, cytotoxic effect was observed against $70 \%$ of MCF-7 and NCI-H460 cell lines, whereby $16 \%$ of hematological tumor cell lines (MOLT-4) showed cytotoxicity (Figure No. 1). 


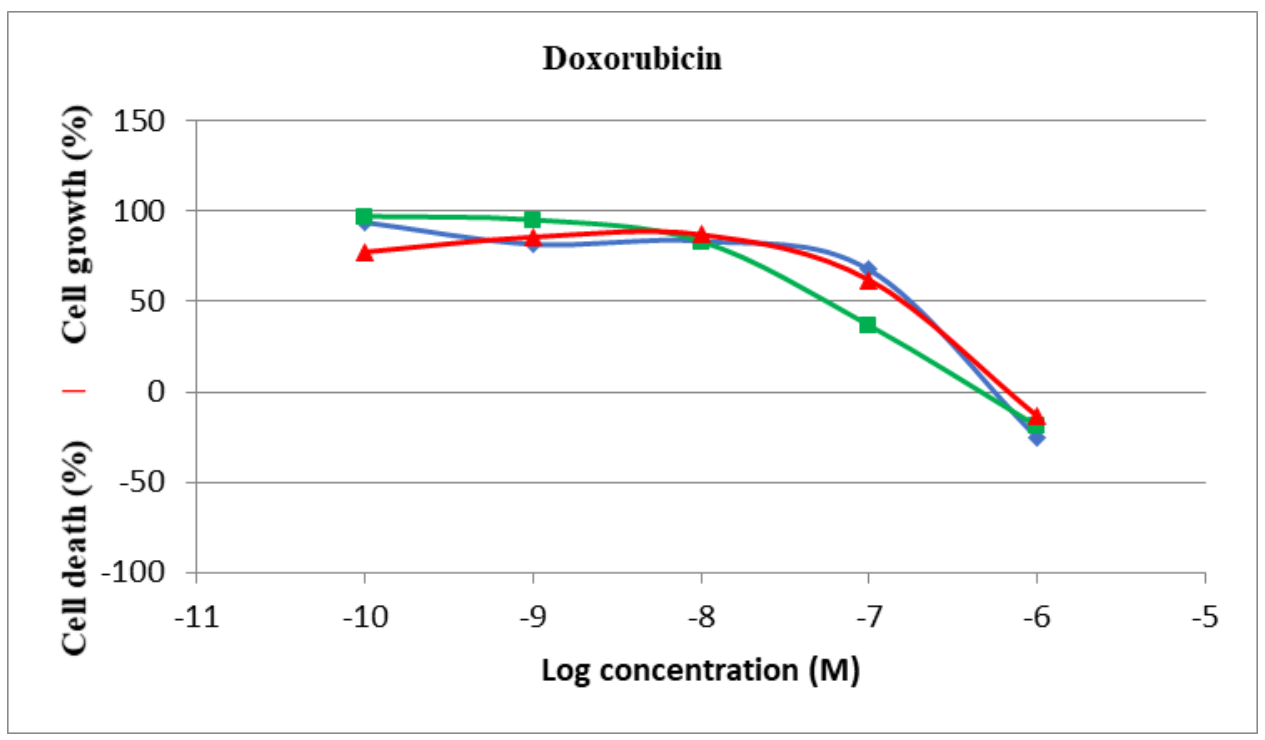

Figure No. 2

Growth inhibition of MOLT-4", NCI-H460 and MCF7 cells in vitro, assessed by MTT assay 72 hours after the addition of doxorubicin

Table No. 2

In vitro antiproliferative activity expressed as $\mathrm{GI}_{50}{ }^{\mathrm{a}}$ values $(\mu \mathrm{g} / \mathrm{ml})$ against MOLT-4, MCF-7 and NCI-H460 tumor cell lines.

\begin{tabular}{lccc}
\hline \multicolumn{3}{c}{ GI $_{50}{ }^{\mathbf{a}}(\boldsymbol{\mu g} / \mathbf{m l})$} \\
\hline Compound & MOLT-4 & Cell lines & \\
Melissae aeth. & $<5$ & MCF-7 & NCI-H460 \\
Doxorubicin & $0,02 \pm 0,01$ & $6 \pm 2$ & $31 \pm 17$ \\
& $(0,003 \pm 0,002 \mu \mathrm{M})$ & $(0.15 \pm 0.04 \mu \mathrm{M})$ & $(0.05 \pm 0.01 \mu \mathrm{M})$
\end{tabular}

${ }^{a}$ GI $_{50} \pm$ SD: the concentration that causes $50 \%$ growth inhibition, as assessed by MTT assay, 72 hours after the addition of the test substances. The results are shown as mean \pm SD from three independent experiments

\section{DISCUSSION}

The above results show that chemical composition of the M. officinalis L. essential oil, native from Bosnia, was dominated by citral $(47.2 \%)$, caryophyllene oxide $(10.2 \%)$, citronellal $(5.4 \%)$, geraniol (6.6\%), geranyl acetate $(4.1 \%)$ and $\beta$-caryophyllene $(3.8 \%)$.
These results are in accordance with previous published data on lemon balm essential oils in Serbia (Bozin et. al., 2006) and Slovakia (Holla et al., 1997). Basta et al. (2005) reported that an oxygenated sesquiterpene, caryophyllene oxide $(12.6 \%)$ was the most abundant constituents in the oil 
of M. officinalis L. from Greece. Also, caryophyllene oxide was identified at $10.0 \%$ in oil from Egypt (Shalaby El-Gengaihi \& Khattab, 1995). However, recent studies of lemon balm oil composition from different regions showed that composition of major components may vary, e.g. de Sousa et al. (2004) reported higher concentrations of geranial $(47.32 \%)$ and neral (39.28\%), but remarkably lower concentrations of caryophyllene oxide $(1.17 \%)$, geranyl acetate $(1.51 \%)$ and $\beta$-caryophyllene $(0.94 \%)$ with absence of geraniol and citronellal in lemon balm essential oil from Brazil (de Sousa et al., 2004).

Our data demonstrated that M. officinalis L. essential oil inhibited the viability of MOLT-4, MCF7 and NCI-H460 cell lines in a concentrationdependent manner. At the concentrations ranging from 5 to $1000 \mu \mathrm{g} / \mathrm{ml}$ a significant effect was observed for each cell line MOLT-4, MCF-7 and NCI-H460 with GI $_{50}$ values $<5 \mu \mathrm{g} / \mathrm{ml}, 6 \pm 2 \mu \mathrm{g} / \mathrm{ml}$, $31 \pm 17 \mu \mathrm{g} / \mathrm{ml}$, respectively. The strongest antiproliferative activity of $M$. officinalis L. essential oil was observed against MOLT-4 cell lines $\left(\mathrm{GI}_{50}<5\right.$ $\mu \mathrm{g} / \mathrm{ml}$ ), resulted in $>80 \%$ of growth inhibition in treated cells at the lowest applied dose $(5 \mu \mathrm{g} / \mathrm{ml})$. This account for the high toxicity profile of $M$. officinalis L. essential oil which requires a lower testconcentrations compared to other evaluated cell lines. As proposed by previous studies (Sylvestre et al., 2006) that performed the cytotoxic effect of essential oils, $\mathrm{GI}_{50}$ values between $10-50 \mu \mathrm{g} / \mathrm{mL}$ represent a strong antiproliferative activity. Moreover, $\mathrm{GI}_{50}$ values between $50-100,100-200$, and 200-300 $\mu \mathrm{g} / \mathrm{mL}$ indicate moderate, weak, and very weak antiproliferative properties, respectively. According to these statements, $M$. officinalis L. essential oil has a strong antiproliferative activity. Furthermore, $M$. officinalis L. essential oil in low concentrations (5-10 $\mu \mathrm{g} / \mathrm{mL}$ ) demonstrated antiproliferative activity for all tested cell lines, but in higher concentrations $(>50$ $\mu \mathrm{g} / \mathrm{mL}$ for NCI-H460 and MCF-7 cell lines, and $>10$ $\mu \mathrm{g} / \mathrm{mL}$ for MOLT-4 cell line) exhibit cytotoxic activity. Solid tumor cell lines (MCF-7 and NCI-H 460) were more sensitive to higher concentrations of M. officinalis L. essential oil than hematological tumor cell lines (MOLT-4). Although, the strongest antiproliferative activity of $M$. officinalis $\mathrm{L}$. essential oil was observed against MOLT-4 cell lines, it can be noticed that plateau effect of cytotoxicity $(16 \%)$ is observed in concentrations of $10-100 \mu \mathrm{g} / \mathrm{mL}$. For all tested cell lines, a high level of cytotoxicity $(76 \%$ -
$96 \%$ ) was observed in concentrations of 500-1000 $\mu \mathrm{g} / \mathrm{mL} M$. officinalis L. essential oil.

The study accomplished by de Sousa and coworkers on lung (A549), colon (Caco-2), breast (MCF-2) and leukemia (HL-60 and K562) human cancer cell lines and in a mouse melanoma cell lines (B16F10) corroborates our results, according to which $M$. officinalis L. essential oil also showed antitumoral activity in a concentration-dependent manner. Apoptosis inducing effects of $M$. officinalis L. essential oil in glioblastoma multiforme cells (GBM) has also been reported (de Sousa et al., 2004). A study by Jahanban and coworkers showed the significant results of hydroalcoholic extracts of M. officinalis L. (MOE) towards A549 (lung nonsmall cell cancer lines), MCF-7, PC-3 (prostate adenocarcinoma) and SKOV3 (ovarian cancer cells) (Jahanban-Esfahlan et al., 2015). In all cancer cells, MOE reduces the cell viability to values below $33 \%$, even at the lowest dose applied $(5 \mu \mathrm{g} / \mathrm{ml})$. The $50 \%$ ethanolic extract reduced colon cancer cell line proliferation (HCT-116) to values close to $40 \%$, even at the lowest dose tested $(5 \mu \mathrm{g} / \mathrm{ml})$ (Encalada et al., 2011). Comparing results obtained from our previous study, which tested antiproliferative activity of Lavandula angustifolia Mill. essential oil it is noticed that the $M$. officinalis L. essential oil has a significantly more potent effect than L. angustifolia essential oil on antiproliferation of tumor cells. $L$. angustifolia essential oil showed antiproliferative activity to MOLT-4, MCF-7 and NCI-H460 cancer cell lines with $\mathrm{GI}_{50}$ values that are significantly higher than $M$. officinalis L. essential oil $\mathrm{GI}_{50}$ values (Nikšić et al., 2017.).

In-vitro antiproliferative and cytotoxic activity of essential oils had been described already (Setzer et al., 1999; Buhagiar et al., 1999; Angelopoulou et al., 2001; Hayes \& Markovic, 2002; Moteki et al., 2002). In some cases, this activity was attributed to specific components of the oil. The chemical complexity of the essential oils as a phytocomplexes contributes to its biological effects, since each constituent takes part in the overall outcome and may modulate the effects of the others. On the other hand, studies on individual ingredients might report results that do not recapitulate the effect of treatment with the phytocomplexes as a whole.

The above results on chemical composition and antiproliferative activity of the oil indicate that these effects may be attributed by the presence of 
specific components such as citral (47.2\%), citronellal $(5.4 \%)$ and geraniol $(6.6 \%)$. The EO component citral has been shown to induce phase II enzymes in a dose-dependent manner (Nakamura et al., 2003). The mechanism of action of citral is due to its geranial isoform component (Nakamura et al., 2003). Recent studies have shown citral to inhibit cell intracellular levels of oxygen radicals and, consequently, by the modulation of cellular oxidative status, leading to reduction of cancer cell proliferation and ultimately resulting in cell death (Kapur et al., 2016; Sanches et al., 2017). Citral was also shown to induce caspase activation and subsequent apoptosis induction in several cancer cell types, including colorectal cancer and glioblastoma (Dudai et al., 2005; Queiroz et al., 2014; Sheikh et al., 2017). Other studies have shown that citral is a is a key component of the essential oils extracted from lemon balm with antiproliferative effect in several leukemia cell lines (P388, NB4, MOLT-4) via the induction of apoptosis (Xia et al., 2013). Recent study demonstrated that citral nanostructured lipid carrier inhibited the proliferation of breast cancer cells in vitro (MDA MBA-231 human breast cancer cells), majorly through the induction of apoptosis, anti-metastasis, anti-angiogenesis potentials, and reducing the tumor weight and size without altering the therapeutic effects of citral (Nordin et al., 2019).

Geraniol has been shown to inhibit the proliferation of human colon cancer cells in-vitro (Carnesecchi et al., 2001) and the growth of pancreatic (Burke et al., 1997), hepatic and skin (Yu et al., 1995) tumors in-vitro and in-vivo. Altshuler et al. (2013), found that the enantiomer (+)-citronellal, a major component of Corymbia citriodora and Cymbopogon nardus EOs, is also an effective microtubule-disrupting compound, similarly to better known microtubule-disrupting agents colchicine and vinblastine (Altshuler et al., 2013).

Also $\beta$-caryophyllene $(3.8 \%)$, caryophyllene oxide $(10.2 \%)$, terpinen-4-ol $(0.4 \%)$ and $\alpha$-terpineol $(0.3 \%)$ have also been demonstrated to act synergistically with other essential oil components to enhance cytotoxic activities (Wright et al., 2007) therefore should be evaluate the synergy between these compounds and their own contribution to the final anticancer activity.

In this work and in the available literature, $M$. officinalis L. essential oil seems to have a potential as anticancer therapeutic agents. Altogether, our data showed that this oil could be a natural source of anticancer compounds with antiproliferative and cytotoxic properties.

\section{CONCLUSION}

The results of our study suggest that the essential oil of $M$. officinalis L. has potential antiproliferative activity against several malignant cell lines (MOLT4, MCF-7 and NCI-H460). The showed activities are differential and selective. The strongest antiproliferative activity of $M$. officinalis L. essential oil was observed against MOLT-4 cell line, resulted in $>80 \%$ of growth inhibition in treated cells at the lowest applied dose. For all tested cell lines, a high level of cytotoxicity was observed. Solid tumor cell lines (MCF-7 and NCI-H 460) were more sensitive to higher concentrations of $M$. officinalis $\mathrm{L}$. essential oil than hematological tumor cell lines (MOLT-4). Thus, from the above obtained results, we can observe that M. officinalis L. essential oil is showing a differential antiproliferative and cytotoxic effect at micromole concentrations, which are suited for further biological studies and optimization.

\section{REFERENCES}

Adams RP. 2007. Identification of essential oil components by gas chromatogramphy/quadrupole mass spectroscopy. 4th Ed, Allured Publishing Corporation: Carol Stream, USA. https://doi.org/10.1016/s10440305(97)00026-3

Altshuler O, Abu-Abied M, Chaimovitsh D, Schechter A, Frucht H, Dudai N, Sadot E. 2013. Enantioselective effects of (+) and (-)citronellal on animal and plant microtubules. J Nat Prod 76: 1598 - 1604. https://doi.org/10.1021/np4002702

Amin A, Gali-Muhtasib H, Schneider-Stock R. 2009. Overview of major classes of plant-derived anti-cancer drugs. Int J Biomed Sci 5: 1 - 11.

Angelopoulou D, Demetzos C, Dimas C, Perdetzoglou D, Loukis A. 2001. Essential oils and hexane extract from leaves and fruits of Cistus monspeliensis. Cytotoxic activity of ent-13-eoi-manoyl oxide and its isomers. Planta Med 67: 168 - 171. https://doi.org/10.1055/s-2001-11497

Basta A, Tzakou O, Couladi M. 2005. Composition of the leaves essential oil of Melissa 
officinalis from Greece. Flavour Fragr J 20: $642-644$.

https://doi.org/10.1002/ffj.1518

Blowman K, Magalhaes M, Lemos MFL, Cabral C, Pires M. 2018. Anticancer properties of essential oils and other natural products. $\mathbf{J}$ Evid Based Complementary Altern Med Article ID 3149362. https://doi.org/10.1155/2018/3149362

Body MR, Kenneth DP. 1995. Some practical considerations and applications of the national cancer institute in vitro anticancer drug discovery screen. Drug Dev Res 34: 91109.

https://doi.org/10.1002/ddr.430340203

Bozin B, Mimica-Dukic N, Simin N, Anackov G. 2006. Characterization of the volatile composition of essential oils of some Lamiaceae spices and the antimicrobial and antioxidant activities of the entire oils. J Agric Food Chem 54: 1822 - 1828.

https://doi.org/10.1021/jf051922u

Buhagiar JA, Podesta MT, Wilson AP, Micallef MJ, Ali S. 1999. The induction of apoptosis in human melanoma, breast and ovarian cancer cell lines using an essential oil extract from the conifer Tetraclinis articulate. Anticancer Res 19: 5435 - 5443.

Burke YD, Stark MJ, Roach SL, Sen SE, Crowell PL. 1997. Inhibition of pancreatic cancer growth by the dietary isoprenoids farnesol and geraniol. J Lipids 32: 151 - 156. https://doi.org/10.1007/s11745-997-0019-y

Carnesecchi S, Bras-Goncalves R, Bradaia A, Zeisel M, Gosse F, Poupon MF, Raul F. 2004. Geraniol, a component of plant essential oils, modulates DNA synthesis and potentiates 5fluorouracil efficacy on human colon tumor xenografts. Cancer Lett 215: 53 - 59.

https://doi.org/10.1016/j.canlet.2004.06.019

Carnesecchi S, Schneider Y, Ceraline J, Duranton B, Gosse F, Seiler N, Raul F. 2001. Geraniol, a component of plant essential oils, inhibits growth and polyamine biosynthesis in human color cancer cells. J Pharmacol Exp Ther 298: 197 - 200.

de Sousa AC, Alviano DS, Blank AF, Barreto AP, Sales C, Rocha GC. 2004. Melissa officinalis $L$. essential oil: antitumoral and antioxidant activities. J Pharm Pharmacol 56: 677 -
681.

https://doi.org/10.1211/0022357023321

DTP. 2016. National Cancer Institute Welcome to the Developmental Therapeutics Program. In: Developmental Therapeutics Program (DTP). https://dtp.cancer.gov

Dudai N, Weinstein Y, Krup M, Rabinski T, Ofir R. 2005. Citral is a new inducer of caspase- 3 in tumor cell lines. Planta Med 71: 484 - 488. https://doi.org/10.1055/s-2005-864146

Edris AE. 2007. Pharmaceutical and therapeutic potentials of essential oils and their individual volatile constituens: a review. Phytother Res 21: 308 - 323. https://doi.org/10.1002/ptr.2072

Encalada MA, Hoyos KM, Rehecho S, Berasategi U, de Ciriano MG-I, Ansorena D, Astiasaran I, Navarro-Blasco I, Cavero RY, Calvo MI. 2011. Anti-proliferative effect of Melissa officinalis on human colon cancer cell cine. Plant Foods Hum Nutr 6: 328 - 334. https://doi.org/10.1007/s11130-011-0256-y

European Pharmacopeia. 2010. Council of Europe European (COE). Cedex, Strasbourg, France.

Hayes AJ, Markovic B. 2002. Toxicity of Australian essential oil Backhousia citriodora (Lemon myrtle). Part 1. Antimicrobial activity and in vitro cytotoxicity. Food Chem Toxicol 40: $535-543$.

https://doi.org/10.1016/s02786915(01)00103-x

Hollá M, Svajdlenka E, Tekel J, Vaverkova S, Havranek E. 1997. Composition of the essential oil from Melissa officinalis L. cultived in Slovak Republic. J Essent Oil Res 9: 481 - 484.

https://doi.org/10.1080/10412905.1997.970 0758

Jahanban-Esfahlan A, Modaeinama S, Abassi M, Abassi MM, Esfahlan-Jahanban R. 2015. Anti Proliferative Properties of Melissa officinalis in Different Human Cancer Cells. Asian Pac J Cancer Prev 16: 5703 - 5707. https://doi.org/10.7314/apjcp.2015.16.14.57 03

Kapur A, Felder L. Fass, Kaur J, Czarnecki A, Rathi K, Zeng S, Osowski KK, Howell C, Xiong MP, Whelan RJ, Patankar MS. 2016. Modulation of oxidative stress and subsequent induction of apoptosis and 
endoplasmic reticulum stress allows citral to decreas cancer cell proliferation. Sci Rep 6: Article ID 27530.

\section{https://doi.org/10.1038/srep27530}

Legault J, Pichette A. 2007. Potentiating effect of $\beta$ caryophyllene on anticancer activity of $\alpha$ humulene, isocaryophyllene and paclitaxel. J Pharm Pharmacol 59: 1643 - 1647. https://doi.org/10.1211/jpp.59.12.0005

Lesgards JF, Baldovini N, Vidal N, Pietri S. 2014. Anticancer activities of essential oils constituents and synergy with conventional therapies: a review. Phytother Res 28: 1423 $-1446$.

https://doi.org/10.1002/ptr.5165

Mimica-Dukic N, Bozin B, Sokovic M, Simin N. 2004. Antimicrobial and antioxidant activities of Melissa officinalis $L$. (Lamiaceae) essential oil. J Agric Food Chem 52: 2485 - 2489. https://doi.org/10.1021/jf030698a

Miraj S, Azizi N, Kiani S. 2016. A review of chemical components and pharmacological effects of Melissa officinalis L. Pharm Lett 8: 229 - 237.

Miraj S, Rafieian-Kopaei M, Kiani S. 2017. Melissa officinalis $L$ : A review study with an antioxidant prospective. J Evid Based Complementary Altern Med 22: 385 - 394. https://doi.org/10.1177/2156587216663433

Moaca EA, Farcas C, Ghitu A, Coricovac D, Popovic R, Caraba-Meita NL, Ardelean F, Antal DS, Dehelean C, Avram S. 2018. A Comparative study of Melissa officinalis leaves and stems ethanolic extracts in terms of antioxidant, cytotoxic, and antiproliferative potential. Evid Based Complement Alternat Med 6: $1-12$. https://doi.org/10.1155/2018/7860456

Moteki H, Hisabami H, Yamanda Y, Katsuzaki H, Imai K, Komiya T. 2002. Specific induction of apoptosis by 1,8-cineole in two human leukemia cell lines, but not in a human stomach cancer cell line. Oncol Rep 9: 757 760.

https://doi.org/10.3892/or.9.4.757

Nakamura Y, Miyamoto M, Murakami A, Ohigashi H, Osawa T, Uchida K. 2003. A phase II detoxification enzyme inducer from lemongrass. Identification of citral and involvement of electrophilic reaction in the enzyme induction. Biochem Biophys Res Commun 302: 593 - 600 . https://doi.org/10.1016/s0006291x(03)00219-5

Nikšić H, Kovač-Bešović E, Makarević E, Durić K, Kusturica J, Muratović S. 2017. Antiproliferative, antimicrobial, and antioxidant activity of Lavandula angustifolia Mill. essential oil. J Health Sci 7: $35-43$. https://doi.org/10.17532/jhsci.2017.412

Nordin N, Yeap SK, Rahman HS, Zamberi NR, Abu $\mathrm{N}$, Mohamed NE, Wun How C, Masarudin MS, Alitheen RA, Alitheen NB. 2019. In vitro cytotoxicity and anticancer effects of citral nanostructured lipid carrier on MDA MBA-231 human breast cancer cells. Sci Rep 9: article ID 1614.

https://doi.org/10.1038/s41598-018-38214-x

Queiroz RM, Takiya CM, Guimaraes LP. 2014. Apoptosis inducing effects of Melissa officinalis $L$. essential oil in glioblastoma multiforme cells. Cancer Invest 32: 226 235.

https://doi.org/10.3109/07357907.2014.905 587

Raby T, Bishayee A. 2009. d-Limonen sensitizes docetaxel induced cytotoxicity in human prostate cancer cells: Generation of reactive oxygen species and induction of apoptosis. $\mathbf{J}$ Carcinog 8: 9. https://doi.org/10.4103/1477-3163.51368

Sadraei H, Ghannadi A, and Malekshahi K. 2003. Relaxant effect of essential oil of Melissa officinalis and citral on rat ileum contractions. Fitoterapia 74: 445 - 452. https://doi.org/10.1016/s0367326x $(03) 00109-6$

Sanches LJ, Marinello PC, Panis C, Fagundes TR, Morgado-Diaz JA, de-Freitas-Junior JC, Cecchini AL, Luiz RC. 2017. Cytotoxic of citral against melanoma cells: The involvement of oxidative stress generation and cell growth protein reduction. Tumour Biol 39 (3). https://doi.org/10.1177/1010428317695914

Saraydin SU, Tuncer E, Tepe B, Karadayi S, Ozer H, Sen M, Karadayi K, Inan D, Elagöz Ş, Polat Z, Duman M, Turan M. 2012. Antitumoral 
effects of Melissa officinalis on breast cancer in vitro and in vivo. Asian Pac J Cancer Prev 13: 2765 - 2770. https://doi.org/10.7314/apjcp.2012.13.6.276 5

Setzer WN, Setzer MC, Moriarity DM, Bates RB, Haber WA. 1999. Biological activity of the essential oil of Myrcianthes sp. Nov. "black fruit" from Monteverde, Costa Rica. Planta Med 65: 486 - 469. https://doi.org/10.1055/s-2006-960816

Shalaby El-Gengaihi AS, Khattab MJ. 1995. Oil of Melissa officinalis L. as affected by storage and herb drying. J Essent Oil Res 7: 667 669.

https://doi.org/10.1080/10412905.1995.970 0525

Sheikh BY, Sarker MMR, Kamarudin NA, Mohan G. 2017. Antiproliferative and apoptosis inducing effects of citral via p53 and ROSinduced mitrochondrial-mediated apoptosis in human colorectal HCT116 and HT29 cell lines. Biomed Pharmacother 96: 834 - 846. https://doi.org/10.1016/j.biopha.2017.10.03 8

Sitarek P, Rijo P, Garcia C, Skala E, Kalemba D, Bialas AJ, Szemraj J, Pytel D, Toma M, Wysokinska H, Sliwinski T. 2017. Antibacterial, anti-inflammatory, antioxidant, and antiproliferative properties of essential oils from hairy and normal roots of Leonurus sibiricus $L$. and their chemical composition. Oxid Med Cell Longev 2017: article ID 7384061 .

https://doi.org/10.1155/2017/7384061

Sylvester PW. 2011. Optimization of the tetrazolium dye (MTT) colorimetric assay for cellular growth and viability. Methods Mol Biol 716: $157-168$. https://doi.org/10.1007/978-1-61779-012-
6_9

Sylvestre M, Pichette A, Longtin A, Nagau F, Legault J. 2006. Essential oil analysis and anticancer activity of leaf essential oil of Croton flavens L. from Guadeloupe. J Ethnopharmacol 103: 99 - 102. https://doi.org/10.1016/j.jep.2005.07.011

Unver SS, Ersin T, Bektas T, Sule K, Hatice O, Metin S, Kursat K, Deniz I, Sahande E, Polat Z, Duman M, Turan M. 2012. Antitumoral effects of Melissa officinalis on breast cancer in vitro and in vivo. Asian Pac J Cancer Prev 13: 2765 - 2770. https://doi.org/10.7314/apjcp.2012.13.6.276 5

Ward E, DeSantis C, Robbins A, Kohler B, Jemal A. 2014. Childhood and adolescent cancer statistics. CA Cancer J Clin 64: 83 - 103. https://doi.org/10.3322/caac.21219

WHO. 2018. International Agency for Research on Cancer In: World Health Organization. https://www.iarc.fr/wpcontent/uploads/2018/09/pr263_E.pdf

Wright BS, Bansal A, Moriarity DM, Takaku S, Setzer WN. 2007. Cytotoxic leaf essential oils from neotropical Lauraceae: synergistic effects of essential oil components. Nat Prod Commun 12: 1241 - 1244. https://doi.org/10.1177/1934578x07002012 10

Xia H, Liang W, Song Q, Chen X, Hong J. 2013. The in vitro study of apoptosis in NB4 cell induced by citral. Cytotechnology 65: 49 57. https://doi.org/10.1007/s10616-012-9453-2

Yu SG, Hildebrandt LA, Elson CE. 1995. Geraniol, an inhibitor of mevalonate biosynthesis, suppresses the growth of hepatomas and melanomas transplanted to rats and mice. $\mathbf{J}$ Nutr 125: $2763-2767$. 